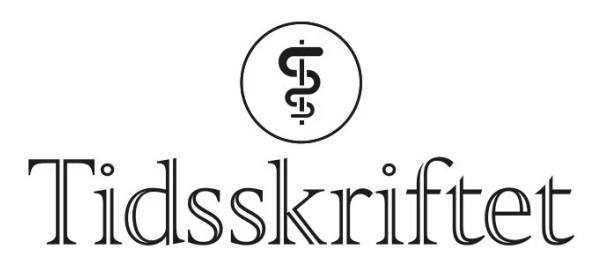

DEN NORSKE LEGEFORENING

\title{
Masseskadetriage - best mulig for flest mulig?
}

LEDER

\section{RUNE RIMSTAD}

rurimstad@mil.no

Rune Rimstad er overlege ved Avdeling for anestesiologi og Luftambulanseavdelingen ved Oslo universitetssykehus, overlege i katastrofemedisin for Forsvaret og konsulent i Avdeling for akuttmedisin og beredskap, Helsedirektoratet. Han har ledet revisjonen av nasjonal veileder for masseskadetriage.

Forfatteren har fylt ut ICMJE-skjemaet og oppgir ingen interessekonflikter.

\section{Togulykker, store branner eller terrorangrep kan føre til at det er mange skadde pasienter samtidig. Hvilke pasienter skal behandles først når ressursknapphet gjør at vi må velge?}

Helsedirektoratet ga i august 2020 ut revidert Nasjonal veileder for masseskadetriage, med faglig grunnlag utarbeidet av Nasjonal kompetansetjeneste for prehospital akuttmedisin $(\underline{1}, \underline{2})$. Kjernen i systemet er et flytskjema for unders $\emptyset$ kelse av pasientens vitale funksjoner (luftveier, respirasjon, sirkulasjon og bevissthet) og skader. Funnene leder til en kategorisering av hastegrad, som gir grunnlag for prioritering av behandling og evakuering. Stanse blødning før smertelindring. Hodeskade til sykehus før ankelbrudd.

Kategoriseringen er ikke nok til å avgjøre hvordan behandlingskapasiteten eller evakueringsressursene skal fordeles, fordi flytskjemaet ikke tar hensyn til praktiske forhold, hvor mange pasienter det er totalt eller hvor hardt skadd de andre pasientene er. Hastegradsvurderingen er kontekstuavhengig og individrettet. Prioriteringene i den videre håndteringen er kontekstavhengig og må ta hensyn til ressurstilgang, transportavstander, vær og det totale skadebildet.

Triagering må gjøres så raskt at prosessen i seg selv ikke gir dårligere behandlingsresultat fordi nødvendige tiltak blir utsatt. Veilederen advarer mot å ta systemet i bruk når det ikke er alvorlig mangel på ressurser. For eksempel kan det ved en bussulykke være mange helt lett skadde og bare et par hardt skadde. Hvis dette enkelt lar seg identifisere, vil det være bedre å hjelpe de åpenbart hardest skadde i stedet for å bruke tiden på triageprosedyrer.

Veilederens etiske utgangspunkt er utilitarismen, en konsekvensetikk som sier at handlingene er riktig dersom de gir størst mengde nytte til alle de involverte i ulykken samlet sett. Systemet skal bidra til at vi gjør «best mulig for flest mulig» (1). Videre 
presiseres det at den «nytten» som skal måles, er overlevelse. Livstruende skadde må behandles først for å redde liv. Dette er et utgangspunkt som gjerne fremstår intuitivt og innlysende (3). Maksimal samlet overlevelse er derimot ikke hele historien, etisk sett.

\section{«Å gjøre best mulig for flest mulig innebcerer ikke bare livreddende tiltak»}

Å gjøre best mulig for flest mulig innebærer ikke bare livreddende tiltak. Også de med lettere skader skal tildeles en skjønnsmessig andel av behandlingsressursene uten å måtte vente til alle alvorligere tilfeller er ferdigbehandlet og evakuert. Det samme gjelder pasienter der livet ikke står til å redde.

Den forrige versjonen av triagesystemet ga barn, og særlig spedbarn, høyere prioritet enn deres kliniske tilstand skulle tilsi. Den nye veilederen har gått bort fra dette, men anbefalingen nå er at blant pasientene med lette skader skal barn og andre sårbare grupper som eldre, gravide og funksjonshemmede prioriteres for transport. Foreldre og barn bør om mulig holdes samlet. I veilederen diskuteres ikke om moralsk ansvar kan påvirke prioritering. Implisitt ligger at gjerningsmannen ved en skoleskyting og bussjåføren som sovnet bak rattet triageres som de andre.

Flytskjemaet gir høy hastegrad både til de som har tegn på at vitale funksjoner er påvirket, og de som åpenbart har livstruende skader. Systemet tar med andre ord hensyn både til pasientenes kliniske tilstand i øyeblikket og til den forventede eller sannsynlige tilstanden noe frem i tid hvis nødvendig behandling ikke blir gitt. Tidsperspektivet er sånn sett vesentlig kortere enn $\mathrm{i}$ andre situasjoner der knapphetsgoder som donororganer skal fordeles, og forventet prognose og nytte over mange år må tas i betraktning. Hvor nyttig pasienten er for samfunnet har heller ikke relevans, i motsetning til ved fordeling av koronavaksiner der helsepersonell kommer langt fram i køen.

«Masseskadetriagering er noe de farreste av oss vil måtte utføre, men som alle legevaktleger og prehospitalmedisinere kan bli satt til på neste vakt»

Masseskadetriagering er noe de færreste av oss vil måtte utføre, men som alle legevaktleger og prehospitalmedisinere kan bli satt til på neste vakt. Å bli satt i en posisjon der man må unnlate å gi nødvendig hjelp er belastende (4). Det krever en omstilling å ta i bruk masseskadetriage. Kunnskap og mental forberedthet bidrar til å beskytte mot psykiske plager i etterkant (4). Å lese veilederen og diskutere med kollegaer kan være et sted å begynne.

\section{LITTERATUR}

1. Nasjonal veileder for masseskadetriage. IS-0380. Oslo: Helsedirektoratet, 2020. https://www.helsedirektoratet.no/veiledere/masseskadetriage Lest 28.8.2020.

2. Masseskadetriage. En kartlegging av triagesystemer for håndtering av alvorlige hendelser og katastrofer. Oslo: Nasjonal kompetansetjeneste for prehospital akuttmedisin, 2019. https://www.nakos.no/mod/forum/discuss.php?d=4282 Lest 28.8.2020.

3. Persad G, Wertheimer A, Emanuel EJ. Principles for allocation of scarce medical interventions. Lancet 2009; 373: 423-31. [PubMed][CrossRef]

4. Brooks SK, Dunn R, Amlôt R et al. Social and occupational factors associated with psychological distress and disorder among disaster responders: a systematic review. BMC Psychol 2016; 4: 18. [PubMed][CrossRef] 
Publisert: 2. oktober 2020. Tidsskr Nor Legeforen. DOI: 10.4045/tidsskr.20.0694

(C) Tidsskrift for Den norske legeforening 2023. Lastet ned fra tidsskriftet.no 26. april 2023. 